\title{
The Fortifications of Chalcis (Evripos/Negreponte/Egriboz), Greece
}

\author{
Stavros Mamaloukos \\ University of Patras, Patras, Greece, smamaloukos@upatras.gr / smamaloukos@geam-mnimeeio.gr
}

\begin{abstract}
The aim of this paper is the study of the now destroyed fortifications of the Greek city of Chalcis (Evripos / Negreponte / Egriboz). Having been an important urban centre during the Early and Middle Byzantine Period, Chalcis was occupied by the Latins after the capture of Constantinople in 1204 and became a significant trade centre of Venice. By the end of the fourteenth century, the city became a Venetian holding. In 1470 the Ottomans captured the city after a brief siege. In 1688 the city was unsuccessfully besieged by the Venetians. And in 1833 it was annexed by the Greek State. In the end of the nineteenth century the fortifications of Chalcis were almost completely demolished during an attempt to reorganize and modernize the city. The fortified medieval city of Chalcis, the Kastro, had the shape of a long, irregular pentagon with maximum dimensions $400 \times 700 \mathrm{~m}$. It was surrounded on three sides, namely the north, west and south, by sea. Along its two other sides, the northeast and the southeast, there was a dry moat. Its fortifications had three gates, one on Euripus bridge and two on the land wall, through which the city was connected with Boeotia and Euboea, respectively. From the study of the fortifications, based on their depictions in old engravings and photographs as well as on some poor and still visible remnants, it appears that until their demolition the city walls retained to a large extent their late medieval form, although they had undergone significant interventions by the Ottomans, mainly on the eve, and just after the siege of 1688. The only surviving part of the city's defences, the fort of Karababa, built on the steep hill of the Boeotian coast, can be dated to this period.
\end{abstract}

Keywords: Chalcis (Evripos / Negreponte / Egriboz), medieval fortifications, fortifications of the early artillery era, Venetian fortifications, Ottoman fortifications.

\section{Introduction}

The great value of the fortifications of Chalcis, which were sadly destroyed in the late nineteenth and early twentieth century, lies primarily on two factors. The first is that the fortifications are directly related to the urban evolution of the important medieval city of Evripos / Negroponte, many aspects of which still remain unanswered. The second factor is that, apparently the fortifications retained various elements of medieval fortification technology, mixed with elements of the transitional defensive architecture of the fifteenth century. The aim of this paper is an overall study of the fortifications, based on their depictions in old engravings and photographs, as well as on some poor and still visible remnants.

\section{History}

The fate of Chalcis during Late antiquity and the Dark Ages that followed is not known. It is reasonable to assume that the city had the same fate as the rest of the major urban centers of the Balkan Peninsula, and gradually transformed into a 
medieval city-castle. Probably between the seventh and ninth centuries the city appears to have been confined to the area around the Euripus Strait. In 1204, the city, as well as the whole island of Euboea, fell to various Latin rulers, the Venetians being one of them. In 1390 the Venetians effectively dominated the city and the island. Chalcis fell to the Ottomans, after a ferocious siege, overseen by Sultan Mehmed II the Conqueror himself. Since then, and until 1833, when the city was incorporated into the newlyfound Modern Greek state, Chalcis, which the Ottomans named Egriboz (Eğriboz), held a prominent position in the hierarchy of the urban centers of the Southern Balkan Peninsula. One of the most significant historical events of that time period was the fierce, but ultimately unsuccessful siege of the city by the Venetians under Francesco Morosini, and his allies, which lasted from July to October 1688. Even though Euboea actively participated in the Greek War of Independence of 1821, the city of Chalcis saw no war action, which allowed it to survive through the ravages of war unscathed (Kontogiannis, 2012, pp. 30-31, 35 and 47; Andrews, 1953 / 2006; Steriotou, 2006).

\section{Description of the fortifications}

The Kastro, i.e. the fortified city of Chalkis, was found at the western-most end of the peninsula which the city occupied during its long history. It had the shape of a long, irregular pentagon with maximum dimensions $400 \times 700 \mathrm{~m}$ from east to west, and from north to south respectively. It was surrounded on three sides, namely the north, the west and the south, by sea walls, while the two other sides, the northeast and the southeast, were lined with land walls. The total area of the fortified enclosure measured 52,5 acres, 9 of which were occupied by the fortifications themselves. In the nineteeth century the fortifications of the Kastro appeared to be an impressive, complex and difficult-to-decipher monumental compound (Figs. 1 and 2). A short description of it follows.

Position 1, which corresponds to the Euripus Strait, was occupied by the Bridge Fort (Figs. 1, $2.1,3,4)$, which was the key to the defense of the city from the side of Boeotia. Despite the fact that the monument has been almost completely obliterated, it can be considered to be adequately documented (Pantelidou-Alexiadou, Mamaloukos, 2006), and a relatively accurate reconstruction of it is possible. Based on its form and evidence given by the coats-of-arms once embedded over its northern gate, the Fort was constructed in the early part of the 1460 s, but had also undergone some repairs, of undefined extent, during the Ottoman period.

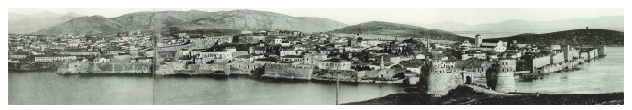

Fig. 1. Chalcis. Kastro. General view from the northeast (between 1884 and 1890), (http://square.gr /newlight-on-negropont/4396).

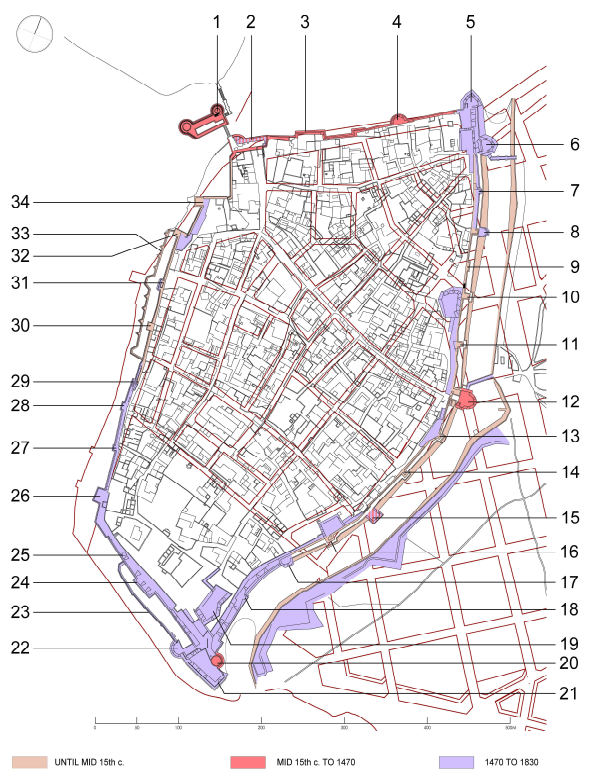

Fig. 2. Chalcis. Kastro. Plan of the fortifications with an indication of the several positions of defense (Modern city's urban tissue in red).

The form of the Euripus Gate, the Porta Marina, which was located in position 2 , is, to a certain extent, known through older depictions and nineteenth century drawings (Figs. 1, 2.2). It appears that up until the 1830s the gate retained the general form it had at the end of the period of Venetian rule, though, most probably somehow modified in certain areas by the Ottomans. 


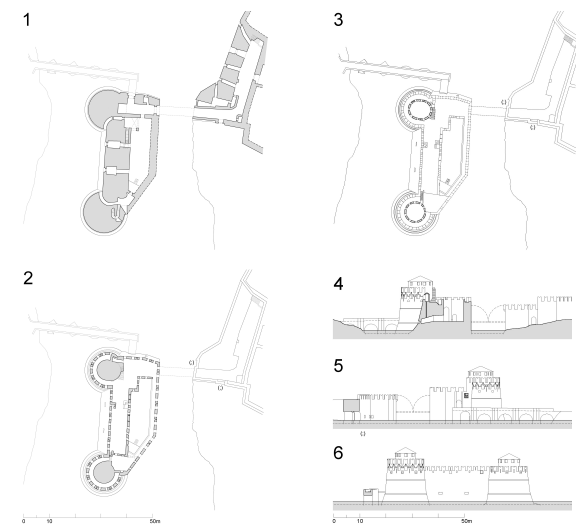

Fig. 3. Chalcis. Kastro. The Fort of the Euripus Bridge and the Porta Marina. Reconstruction (early 19th c.).

The northern sea wall of the Kastro (Figs. 1, 2.2, 4,5 ) (position 2 - position 5) had a length of 250 $\mathrm{m}$. It was reinforced with one projection (position 3) and a small semicircular bastion (position 4). The sea wall largely resembled the typical, and well-known from the fortifications of Nafpaktos and Nafplion, form of fortifications of the third quarter of the fifteenth century (Mamaloukos, 2017, pp. 6-7) (Figs. 9 y 10), namely a slightly inclined exterior face, a narrow rampart-walk protected with a thin parapet with crenellations topped with a v-shaped crown. Based on available evidence, it can been argued that the wall was built or radically rebuilt during the last years of Venetian rule, and that it had undergone repairs during the period of Ottoman rule.

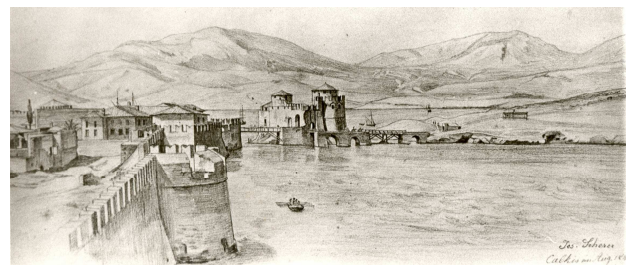

Fig. 4. Chalcis. Kastro. The northern sea wall. View from the north (J.Scherer 1844), (PantelidouAlexiadou, K. - Mamaloukos, S. (2006) Fig. 3).

A bastion with a triangular layout (Figs. 1 and 2.5) rose in the northeastern corner of the fortifications (position 5). The so called Lower Gate of the Kastro (position 6) (Figs. 1 and 2.6) was found a short distance away from the northeastern corner (position 6). Behind the bastion of the gate, on the interior of the land wall there rose a second, internal bastion, which functioned as a cavalier.

Undoubtedly, the sum of the fortifications in the northeastern corner of the Kastro (positions 5 and 6) had assumed its final form during the period of Ottoman rule, possibly in preparation for the Venetian attack of 1688 . However, as this very section of the fortifications saw heavy fighting between the Venetian attackers and the Ottoman defenders during the siege of 1688 , it is most probable that it suffered substantial damage, and it must be assumed that the fortifications were repaired right after the attack.

The land walls of the Kastro (position 5 - position 20) had a length of approximately $800 \mathrm{~m}$. (Fig. 1, 2.5, 2.20). A large section of these walls, namely from position 6 to position 17, as it survived up to the nineteenth century, right before it was demolished, displayed the characteristics of a typical medieval defensive line, with a main curtain wall, an outer wall and a moat. The main wall, portions of which have been discovered during excavations, had a thickness of 3,5 to 4 $\mathrm{m}$, an estimated height of approximately $12 \mathrm{~m}$ and was crowned with a rampart walk protected with a parapet with crenellations.

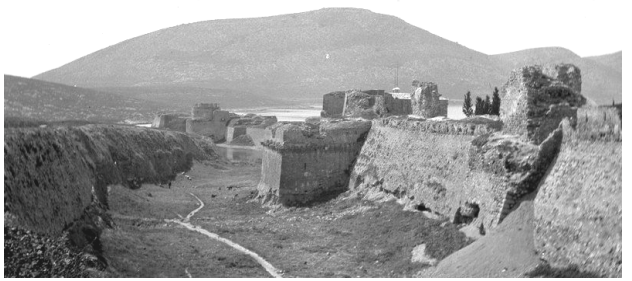

Fig. 5. Chalcis. Kastro. The land wall (positions 13 to 21). View from the north (John Linton Myres c.1900), (http://heir.arch.ox.ac.uk/pages/search.php?search=cha lcis \&archive $=0 \&$ restypes $=1 / 6216$.tif).

Along a substantial part of the walls, namely from position 7 up to position 15, these crenellations were topped with a v-shaped crown, a typical feature in Venetian fortifications of the fourteenth and fifteenth century. The walls were reinforced with towers along regular intervals. Along a large part of the walls, namely form po- 
sition 9 up to position 17, the distances between these towers had a standard length of about 50 $\mathrm{m}$. Most of the towers had maximum plan dimensions of $7 \times 5-7 \mathrm{~m}$. Some of them, such as the one in position 8 , were not integral to the wall, but rather subsequent additions.

In front of the main curtain wall there was an outer wall that had the form of a simple parapet with battlements on a steeply inclined retaining wall (scarpa) (Fig. 2, 5). The outer wall was reinforced with simple tower-like protrusions, about $10 \times 3 \mathrm{~m}$ in dimensions that corresponded with the main wall's towers. In position 15 , in particular, the outer wall was reinforced with a primitive artillery bastion (Fig. 2.5, 5) instead of the typical tower-like structure. A dry moat with an approximate width of $40 \mathrm{~m}$ and an estimated depth of $12 \mathrm{~m}$ was formed along the entire length of the land walls. Undoubtedly, both the walls and the remaining fortifications structures adjacent to it, that are described above, are medieval structures that predate the Ottoman conquest of 1470 .

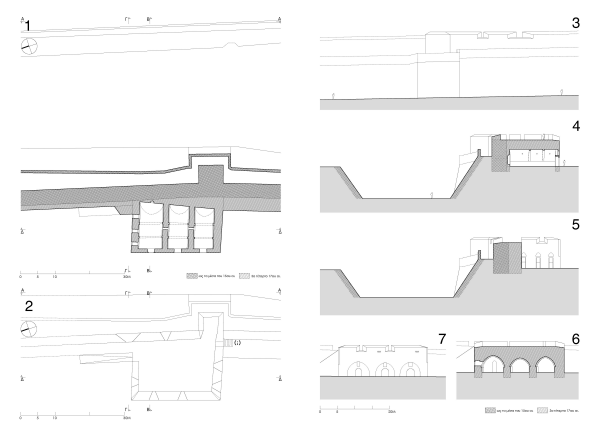

Fig. 6. Chalcis. Kastro. The land wall (position 16). Reconstruction (early nineteenth century).

The part of the wall between positions 6 and 8 had a thickness of about 7,5 m. As can been seen in the portions of the wall that have been excavated, this increase in width resulted from the construction of a rubble masonry wall $1.60 \mathrm{~m}$ away from the exterior face of the wall, and the infill of the interval between the two. The land wall was also thicker in the area between positions 10 and 12, as well as between 15 and 17. In these two areas the added thickness was towards the interior of the initial wall. The part of the wall between positions 17 and 20 (Figs. 1 and 5) had a completely different form compared to the rest of the land wall. In this area the wall had a thickness of about $15 \mathrm{~m}$ and a very thick parapet with cannon ports.

In position 10, a massive internal bastion stood on the interior of the old land wall (Fig. 2.10). One more bastion, similar in function, but with a different form than that found in position 10 reinforced the interior face of the wall in position 16 (Figs. 2.16 and 6). This is the only part of the fortifications that survived the nineteenth century destruction. It has a rectangular plan with dimensions $25,50 \times 16,75 \mathrm{~m}$ and vertical walls. Its terraced roof stood at the same level as that of the terraced roof of the adjacent tower in position 16. On its interior this building had three long halls covered with pointed-arch barrel vaults.

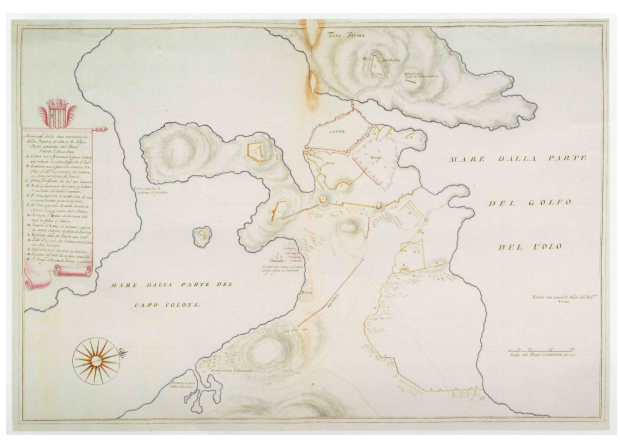

Fig. 7. The siege of Chalcis by the Venetians (1688), (Grimani Collection) (Andrews, K. (2006) pl. XXXV).

In the drawing that depicts the siege of 1688 (Andrews, 1953 / 2006, pl. XXXV; Steriotou, 2006, pl. 1-2,3-4,5-6.11-12, 13, 15-16, 17, 1819) (Fig. 10) but also in the City Planning Diagram of 1840 (Fig. 2) one can clearly make out on the far side of the moat, and in direct correspondence with positions 15 and 20 , the earthworks that formed the, well known from sources, exterior counterscarps (ridotti) which were constructed in preparation for the 1688 attack.

It cannot be doubted that all the defensive structures related to the land wall described above date to the Ottoman period. Their accurate dating, however, is not easy. It is most probable that most of these structures were built to prepare for the anticipated Venetian attack, some- 
time between 1686 and 1688. However, some part of them must date to the years following the siege, and thus be related to the repairs of the damage caused then.

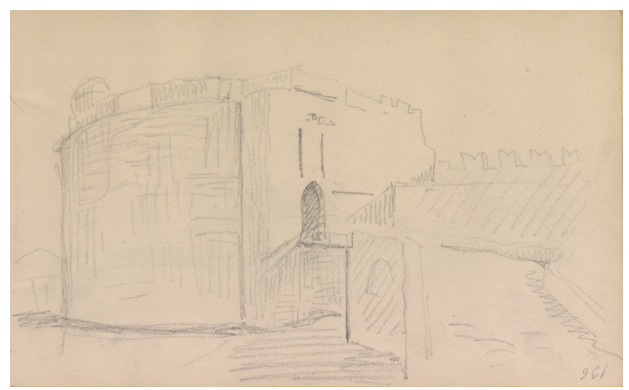

Fig. 8. Chalcis. Kastro. The Upper Gate (position 12). View from the north (Chr. Hansen 1838), (Katsos, V. (2017).

The Upper Gate of the Kastro (Fig. 2.12,6) was found in position 12 of the fortifications. The gate, as it was preserved up to the nineteenth century, had the form of a peculiar bastion with a rectangular plan, approximately $25 \times 22 \mathrm{~m}$ in dimensions; a semicircular structure with a diameter of about $20 \mathrm{~m}$ was attached on the eastern, main façade of it. Upon closer inspection, the depiction of the gate in the City planning Diagram of 1840 shows that on the western side of this bastion, namely the one facing the city, two (?) other towers that belong to an older, medieval construction phase of the gate were incorporated into it. Thus, the dating of the Upper Gate bastion is quite difficult. Based on the form of the gate opening on its southern face and the detail of a winged lion (?) that can be discerned on an old depiction of the gate, together with its overall shape, the bastion must be dated to the last years of the period of Venetian rule. On the other hand, it can also not be ruled out that at least part of this defensive structure was a product of the early Ottoman period.

On the southeastern corner of the fortifications (position 21) rose an imposing, rectangular bastion, with approximate dimensions $50 \times 25 \mathrm{~m}$, inclined exterior faces and a parapet equipped with cannon ports, that boldly projected into the sea (Figs. 2.21 and 5). An exceptionally interesting defensive structure that appeared like a large, circular tower (torrione) typical of the transitional period of artillery adoption, was partly in- corporated into this bastion's northern side (position 20); this structure can be classified as an early circular bastion (Figs. 2.20 and 5). In this case as well, an accurate dating of this structure is not easy. It could be tentatively dated, though with some reservations, to the last years of Venetian rule, and may be related to the rivellino of Vourkos, that is mentioned in sources (Kontogiannis, N. (2012) 38). However, we cannot rule out the possibility that it might have been constructed immediately after the conquest of Chalcis, given also that we do know that the Venetian fortifications of Vourkos suffered heavy damage during the siege of 1470 .

The southern sea wall of the fortified city of Chalcis that stretches between positions 20 and 26 (Fig. 2.20 and 2.26), which is referred to in sources as the Wall of Vourkos, after the name of the shallow cove to the south of the Kastro, had a length of approximately $200 \mathrm{~m}$ and height of about $11 \mathrm{~m}$. Its outline followed a broken line, with a $30 \mathrm{~m}$ long part of it projecting outwards 8 $\mathrm{m}$ on the east and $4 \mathrm{~m}$ on the west (position 24). The wall had the typical form of the fortifications of the age of artillery; it was solid, and had a width ranging from 10 to $15 \mathrm{~m}$, its exterior face was slightly inclined, and it possessed a thick parapet with cannon ports. In position 24 the wall was reinforced with a rectangular projection. In position 26, which can be considered to be the end of the wall of the Vourkos, there was a rectangular bastion. An outer wall, in the form of a proper wall, stood in front of the Wall of Vourkos (position 23) (Fig. 2.23). On the eastern end of this outer wall there was a small semicircular bastion (position 22). In position 19 , on the corner between the land wall and the sea wall of the Vourkos there was a freestanding internal bastion on the internal side of the fortifications (Fig. 2.19).

With the possible exception of the torrione of position 20, all the fortifications of the Vourkos (positions 19-26) can without doubt be dated to the Ottoman period. Even in this case, though, accurately dating these structures is not easy. Even though, based on their form, most of the fortification elements appear to date to the time period around the 1688 siege, it cannot be ruled 
out that part of them might date to the early years following the conquest of 1470 .

The western sea wall of the Kastro (from position 26 to position 2) (Figs. 1, 2.2, 2.26) had a length of approximately $450 \mathrm{~m}$. Its outline followed a broken line, with two major recessed parts towards its northern end. Based on available evidence, we may suggest, with some reservations, that this part of the wall was constructed during the early Ottoman period. The north part of this wall (position 29 - position 2) had a thickness of about $3,5 \mathrm{~m}$ and a height of $15 \mathrm{~m}$. It was reinforced with a tower and three tower-like protrusions. An impressive, rectangular tower rose up in position 30 (Figs. 1 and 2.30). Its dimensions were $8,5 \times 7,5 \mathrm{~m}$ and its total estimated height would have reached over $25 \mathrm{~m}$. An outer wall stood in front of part of the western sea wall (position 33), which had the form of a low wall built $10 \mathrm{~m}$ away from the main wall face.

Both the area delineated by the outer wall, and the two recesses on the northern end of the western wall, obviously aimed at creating open spaces on the beach immediately to the south of the Euripus Bridge, which appear to be related to the operation of the southern port of the city. The famous tide mills of Euripus are thought by many researchers to have been located in the area of the northern-most recess of the wall (Koumanoudis, 2006). Based on available evidence, it can be argued that the northern part of the western sea wall was largely a medieval structure. It appears to have been constructed, either in its entirety, or at least in large part, during the late years of Venetian rule. Undoubtedly, though, this part of the wall must have also undergone repairs during the period of Ottoman rule as well.

The Fort of Karababa (Fig. 9) stands on the hill by the same name that dominated the Boeotian coast across the city of Chalcis, and was constructed by the Ottomans in 1686 , in the overall effort to prepare the city for the impending Venetian offensive (Andrews, 1953 / 2006, pp. 188-191, Fig.199-201; Zivas, 1968a, 1968b).

Chalcis also possessed a series of fortification works (Fig. 7), apart from the fortifications of the Kastro and the Fort of Karababa, all constructed between the years 1686 and 1688, in light of the Venetian offensive (Andrews, 1953 / 2006, pp. 183-185, 191, pl. XXXV; Steriotou, 2006; Kontogiannis, 2012, pp. 47-48), aimed at not only defending the suburb of the city from the attackers, but also to create a second line of defense, to divert the besiegers' fire away from the main fortifications. For this reason, four posts for cannon batteries were created on key high ground positions around the city. These external fortifications were largely crude structures made of stakes and earth, no trace of which, of course, survives today.
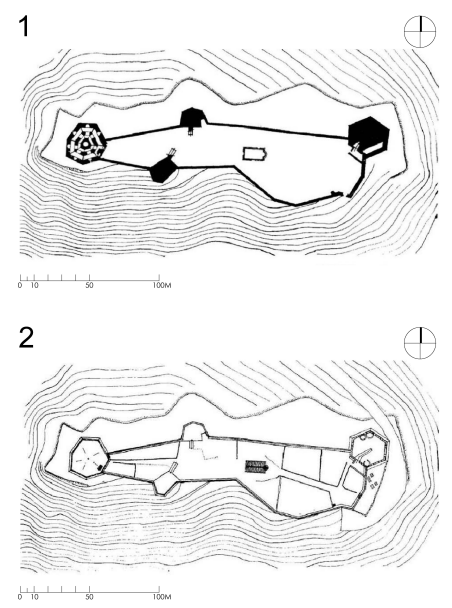

Fig. 9. The Fort of Karababa. (Zivas, D. (1968a) Fig. 4,5).

\section{The fortifications of Chalcis in the overall scheme of medieval and Ottoman fortification architecture}

The medieval phases of the fortifications of Chalcis can be distinguished into two groups. In the first group we must include the parts of the fortifications that are composed of relatively thin walls, with vertical faces and a rampart walk protected with a thin parapet with battlements, reinforced at regular intervals with rectangular towers. The parts of the land walls of this phase were reinforced with an outer wall with towerlike protrusions that corresponded to the main wall towers. An outer wall also partly reinforced the sea walls of the fortifications. The form of the first group of fortifications is typical of medieval fortifications in general. The dating of the structures of the first group is nowadays diffi- 
cult, if not impossible, due to the lack of surviving evidence. Right from the outset it must be noted that these must have included structures of more than one construction phases. The later structures probably date to the late Middle Ages. In terms of the dating of the older phases, it has been suggested that these might even date back to Byzantine times (Kontogiannis, 2012, pp. 33, 37). However, since none of the evidence that have led to this notion is indisputable, it is safer to say that they were constructed sometime in the Middle Ages.

The second group includes those parts of the fortifications (walls and towers / torrioni) that in most cases possess an inclined exterior face (scarpa) and a thick parapet with crenellated battlements, and in some instances some form of early cannon port. These parts of the fortifications can be correlated with the those of Nafplio (Napoli di Romania), such as Bourzti (1471), the Gambello Wall (1473) and parts of the Castle of Toron at Acronafplia (Brooks, 2019), as well as parts of the fortifications of Nafpaktos (Lepanto) (Mamaloukos, 2017, p. 6), and be dated to the third quarter of the fifteenth century; these structures can be thought to correspond to the interventions that, according to sources, the Venetians carried out in preparation for the impending Ottoman onslaught.

The Ottoman phases of the fortifications can be subdivided into four groups. The first group must include the repairs that the fortifications of the Kastro undoubtedly received immediately after the conquest of 1470 , in order to remedy the damage caused by the fierce siege, as well as, possibly, some new structures aimed at modernizing the fortifications in general. The second group consists of interventions on the fortifications made in the period between the late fifteenth and a little after the mid-seventeenth century, to remedy natural wear and deterioration due to natural and other factors. A third group includes Ottoman interventions intended to reinforce the fortifications in light of the Venetian offensive during the Sixth Ottoman-Venetian War (1684-1699), as well as repair of damage suffered during the siege of 1688 .

During the reinforcement of the city's fortifications on the eve of the 1688 attack, minimal work was carried out on the northern and western sea walls, while the central and larger part of the land walls of the enclosure was bolstered with local, whenever possible, interventions, which did not drastically alter its medieval character. The main focus of the Ottoman interventions was the reinforcement of the southern part of the fortifications, which was recognized to be the weaker section of the Kastro, both because it faced the shallow cove of Vourkos, and, primarily, since it would be subjected to heavy canon battery fire that would inevitably be set up on the heights across from it. The northeastern corner of the fortifications was also another area where the Ottoman reinforce-ments focused on.

Despite the fact that the reinforcement interventions of the fortifications of Chalcis were, at least in part, carried out according to the directions of Italian renegade Girolamo Galoppo of Guastalla (Andrews, K. (1953 / 2006) 183), their design, with only a few exceptions and even then only partially, never adopted the principles of the bastion fortification system (fronte bastionato) that was already established and in use in the western world long ago. Thus, all the aforementioned fortification works can be said to be characterized by a sort of conservatism and improvisation, which, after all, are the main typical features of the majority of late Ottoman fortification works (Nicolle, 2010, pp. 4-5). Lastly, a fourth group includes any interventions that the fortifications received in the period between the early eighteenth century and the Greek War of Independence of 1821, to repair natural wear and tear, or damage suffered during the hostilities, or to upgrade and reinforce them during this war.

\section{Acknowledgments}

I wish to express my gratitude to Nikos Kontogiannis, Charalambos Farantos, Maria Floutsakou, Vagias Katsos and Giannis Mytalas for their assistance. The measured drawings that illustrate the paper have been drafted after my instructions by architects Michalis Papavarnavas, Grigoris Koutropoulos, Chrysovaladis Basoukos and Petros Perrakis, whom I profoundly thank. 


\section{Bibliography}

Andrews, K. (1953 / 2006). Castles of the Morea, Revised Edition Ed., Princeton-New Jersey.

Brooks, A. (2019). The Fortifications of Nafplio, Aetos Press Ed., Huddersfield.

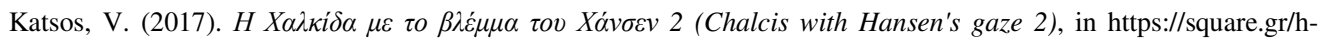
xalkida-me-to-vlema-tou-hansen-meros-2/28516 (14-09-2018).

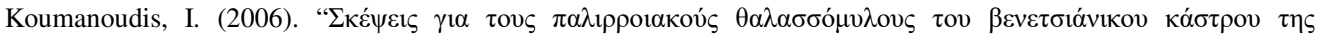
$\mathrm{X} \alpha \lambda \kappa i \delta \alpha \varsigma$ (Some Thoughts on the Tidal Sea-Mills of the Venetian Castle of Chalcis)", Maltezou, Ch., Papakosta,

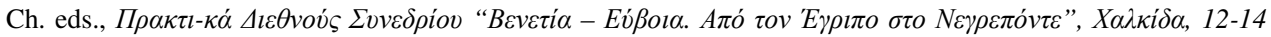

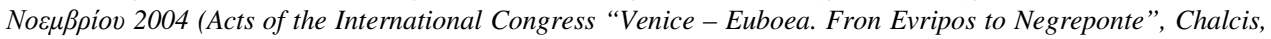
12-14 November 2004), Venice - Athens, pp. 319-346.

Kontogiannis, N. (2012). "Euripos-Negroponte-Eğriboz: Material culture and historic topography of Chalcis from Byzantium to the end of Ottoman Rule", Jahrbuchder Österreichischen Byzantinistik, 62, pp. 29-56.

Mamaloukos, S. (2017). "The 15th c. Venetian Fortifications of Nafpaktos (Lepanto), Greece”, in González-Avilés, A.B. ed., FORTMED 2017, Defensive Architecture of the Mediterranean. XV to XVIII Centuries, Proceedings of the International Conference on Modern Age Fortifications of the Mediterranean Coast, Universitat d'Alacant Ed., Alacant, vol. 6, pp. 153-160.

Nicolle, D. (2010). Ottoman Fortifications 1300-1710, Osprey Publishing Ed., Oxford.

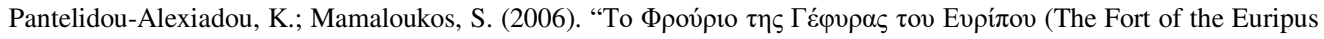

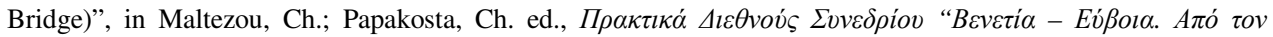

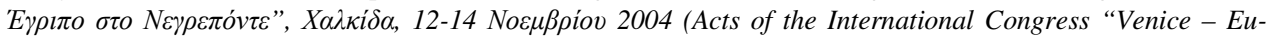
boea. Fron Evripos to Negreponte”, Chalcis, 12-14 November 2004, Venice - Athens, pp. 293-318.

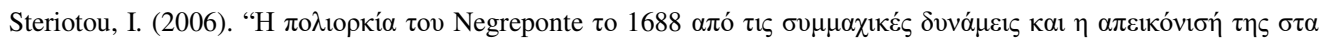
$\beta \varepsilon v \varepsilon \tau \iota \kappa \alpha ́$ $\alpha \rho \chi \varepsilon i ́ \alpha$ (The 1688 Siege of Negreponte by the Allied Forces and its depiction in the Venetian Ar-

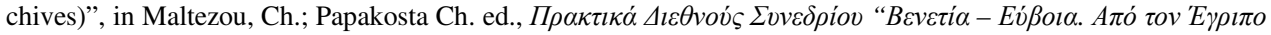

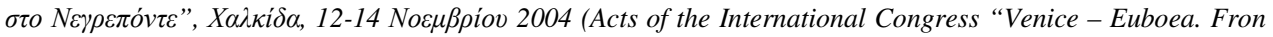
Evripos to Negreponte”, Chalcis, 12-14 November 2004, Venice - Athens, pp. 373-403.

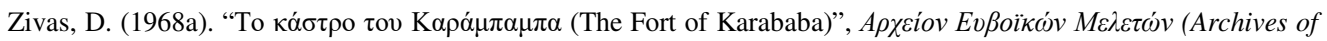
Euboean Studies), 14.

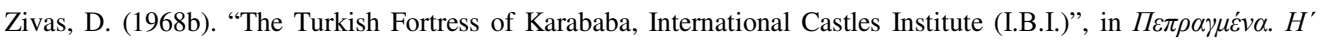

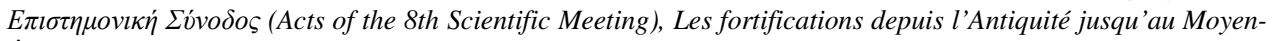
Âge dans le monde méditerranéen, TEE, Athens, pp. 147-156. 